\title{
チタン上への多層リン酸カルシウムコーティング膜の作製とその評価
}

\author{
上田 恭介的 1 , 川㠃 雄城的 1 , 後藤 孝的 2 , 栗原 淳的 3 , 川村 仁的 3 , 成島 尚之的 1 \\ 的東北大学大学院工学研究科材料システム工学専攻，９980-8579 仙台市青葉区荒巻字青葉 6-6-02. \\ 部 2 東北大学金属材料研究所, 厂 980-8577 仙台市青葉区片平 2-1-1. \\ 的 3 東北大学大学院歯学研究科影顔面外科学分野, $=980-8575$ 仙台市青葉区星陵町 4-1.
}

\section{Fabrication and Evaluation of Multi-layered Calcium Phosphate Coating Film on Titanium}

\author{
Kyosuke Ueda ${ }^{\text {th } 1}$, Yuuki Kawasaki ${ }^{\text {is } 1}$, Takashi Goto ${ }^{\text {th } 2}$, Jun Kurihara ${ }^{\text {t子 } 3}$, \\ Hiroshi Kawamura ${ }^{\text {th } 3}$ and Takayuki Narushima ${ }^{\text {th } 1}$ \\ ir 1 Department of Materials Processing, Tohoku University, 6-6-02 Aza Aoba, Aramaki, Aoba-ku, Sendai 980-8579, Japan. \\ मे 2 Institute for Materials Research, Tohoku University, 2-1-1 Katahira, Aoba-ku, Sendai 980-8577, Japan. \\ ${ }^{\text {is }}$ Department of Maxillofacial Surgery, Tohoku University, 4-1 Seiryo-machi, Aoba-ku, Sendai 980-8575, Japan.
}

Received January 7, 2010

\section{SYNOPSIS}

Double-layered calcium phosphate coating films consisting of layers with different crystallinity and composition were fabricated on titanium substrates by RF magnetron sputtering. The first layer of the double-layered coating film, i.e., the inner layer, was made of calcium phosphate having high crystallinity, the second layer, i.e., the outer layer, was made of calcium phosphate having low crystallinity. A double-layered HAp/OAp coating film was fabricated on the titanium substrate; as an inner layer, an HAp film was prepared on the titanium substrate by heat treatment of an OAp film in air at $873 \mathrm{~K}$ for $7.2 \mathrm{ks}$, and then, the HAp layer was coated with the OAp film. In the fabrication of a double-layered OAp/ACP coating film, the inner OAp and the outer ACP films were coated on the titanium substrate under different sputtering conditions. The thickness of the single layer was controlled to be $0.5 \mu \mathrm{m}$, and the total thickness of these double-layered coating films was around $1 \mu \mathrm{m}$. The coating film that comprises the double-layer was dense with a uniform thickness, and the two layers were in close contact with each other. The bonding strength of the HAp/OAp coating film was greater than $50 \mathrm{MPa}$. As in vivo evaluation, the removal torque of $\mathrm{HAp} / \mathrm{OAp}$-coated titanium implants from the femur of Japanese white rabbits was measured. The value of this torque was considerably higher than that of the removal torque of non-coated titanium implants. The outer OAp layer with low crystallinity appeared to dissolve after the 4-week implantation, while the inner HAp layer remained intact and was directly attached to the new bone.

\section{KEY WORDS}

amorphous calcium phosphate, oxyapatite, hydroxyapatite, multi layer, sputtering

\section{1 緒 言}

チタンおよびチタン合金は優れた機械的特性, 而食性およ び金属系材料中では唯一骨と光学顕微鏡レベルで接着する特 性 (osseointegration) を有するため ${ }^{1,2)}$, 人工股関節ステム部や 人工歯根といった骨との密着性が求められる部位に用いられ ている ${ }^{3,4)}$. 骨との密着性向上を目的としたチタン系材料の 表面処理に関しては多くの研究がなされているが5-7), その中 でもリン酸カルシウムコーティングは有効な手段の一つで あり, プラズマスプレー法によるハイドロキシアパタイト $\left(\mathrm{Ca}_{10}\left(\mathrm{PO}_{4}\right)_{6}(\mathrm{OH})_{2}, \mathrm{HAp}\right)$ コーティングは実用化されている.
当グループでは, 低温プロセスで基板との高い密着力を有す る均一かつ緻密な膜を作製できる RF マグネトロンスパッタ リング法に着目し, チタン系材料上へのリン酸カルシウム単 層コーティング膜の作製および評価に関する研究を行ってき た ${ }^{8-13)}$. そして, スパッタリング条件の変化により結晶性の 異なった非晶質リン酸カルシウム $(\mathrm{ACP})$ と結晶質のオキシア パタイト $\left(\mathrm{Ca}_{10}\left(\mathrm{PO}_{4}\right)_{6} \mathrm{O}, \mathrm{OAp}\right)$ が得られること ${ }^{8}$, 大気中の熱処 理によりACPやOApの結晶性が向上することを示した ${ }^{13)}$. 結 晶性の高いリン酸カルシウムコーティング膜は擬似体液中な どの水溶液環境下でも基板との高い密着力の保持に有効であ 
り ${ }^{9)}$ ，結晶性の低いリン酸カルシウムコーティング膜は骨形 成能が高いことが動物埋入実験から示唆されている ${ }^{10-13)}$.

以上を踏まえ, 本研究では基板との密着力に優れた結晶質 リン酸カルシウム膜がチタン基板側に, 高い骨形成能が示唆 される低結晶性リン酸カルシウム膜が生体側になるような二 層コーティング膜に着目した.これまで報告されている RF マグネトロンスパッタリング法によるチタン系材料へのリン 酸カルシウムコーティングの中で, 二層コーティング膜や傾 斜膜を作製しているものは, ターゲット中のHAp/チタン比を 変化させ, 基板から表面へと Ti/HAp比を減少させている ${ }^{14-17)}$ ものであり,リン酸カルシウムコーティングの構成相を制御 している報告はない，

そこで本研究では，基板ノコーティング膜界面では高い密 着性を有する結晶質リン酸カルシウム相，コーティング膜/ 生体界面では高い骨形成能を有する低結晶性リン酸カルシウ ム相となるような多層コーティング膜の作製およびその生体 内外評価を目的とした。

\section{2 試料および実験方法}

\section{1 二層リン酸カルシウムコーティング膜の作製}

基板には鏡面研磨を施した工業用純チタン(CPチタン, 2 種) およびブラスト処理を施した Ti- 6 mass\% Al-4 mass\%V (Ti$6 \mathrm{Al}-4 \mathrm{~V})$ 合金板 $(10 \times 10 \times 1 \mathrm{~mm})$ を用いた。 それぞれの平均表 面粗さは $\mathrm{Ra}<0.05 \mu \mathrm{m}$ および $\mathrm{Ra}=4.6 \mu \mathrm{m}$ であり，これ以降鏡 面研磨基板およびブラスト処理基板と表記することとする。 エタノール中および超純水中でそれぞれ $0.6 \mathrm{ks}$ の超音波洗浄 後, 成膜に供した.

二層リン酸カルシウムコーティング膜として HAp/OAp コーティング膜および OAp/ACP コーティング膜を, 高密度 $\beta$ 型リン酸三カルシウム $\left(\mathrm{Ca}_{3}\left(\mathrm{PO}_{4}\right)_{2}, \mathrm{TCP}\right)$ 焼結体ターゲットを 用いた RF マグネトロンスパッタリング法により作製した. 基板をチャンバー内にターゲットの対向位置となるように設 置し $5 \times 10^{-4} \mathrm{~Pa}$ 以下となるまで真空引きした後，コーティン グ膜の作製を開始した. 作製条件をまとめたものをTable 1 に 示す.成膜時間 $\left(t_{\mathrm{depo}}\right)$ は第一層および第二層の各コーティング 膜の厚さが $0.5 \mu \mathrm{m}$ となるように設定した.いずれの成膜プロセ ス中においても基板の加熱は行わなかったが，最大で $373 \mathrm{~K}$ 程度まで上昇した. HAp/OAp コーティング膜においてはAr$\mathrm{O}_{2}$ スパッタガス中の酸素濃度 $\left(C_{\mathrm{O}_{2}}\right)$ を $50 \%$ とし, チャンバー
内ガス圧力 $\left(P_{\mathrm{tot}}\right)$ を $0.5 \mathrm{~Pa}$ に調整した後, $\mathrm{RF}$ 出力 $(P)=150 \mathrm{~W}$, $t_{\text {depo }}=9.6 \mathrm{ks}$ の条件において OAp コーティング膜を作製した. 第一層成膜後チャンバー内から試料を取り出し, 基板ごと大 気中において $873 \mathrm{~K}, 7.2 \mathrm{ks}$ の熱処理により OApコーティング 膜の結晶化度を向上させた後, 炉冷した. 冷却後の試料を再 度チャンバー内に設置し， $P=100 \mathrm{~W}, P_{\mathrm{tot}}=0.5 \mathrm{~Pa}, C_{\mathrm{O}_{2}}=0 \%$, $t_{\mathrm{depo}}=3.6 \mathrm{ks}$ の条件において成膜し, 第二層とした. OAp/ACP コーティング膜においては, $P=150 \mathrm{~W}, P_{\mathrm{tot}}=5 \mathrm{~Pa}, C_{\mathrm{O}_{2}}=0 \%$, $t_{\mathrm{depo}}=13.1 \mathrm{ks}$ の条件においてスパッタリングすることで第一層 であるOApコーティング膜を作製した. スパッタリング終了 後, 基板温度が室温程度となるまでチャンバー内で泠却し, 試料を取り出すことなく第二層であるACPコーティング膜を 作製した. 第二層の成膜条件は $P=100 \mathrm{~W}, P_{\mathrm{tot}}=0.5 \mathrm{~Pa}, C_{\mathrm{O}_{2}}=0 \%$, $t_{\text {depo }}=3.6 \mathrm{ks}$ とした.

2.2 生体内外評価

鏡面研磨基板上に作製された各コーティング膜の相は，低 角入射 X 線回折 ( $\alpha-2 \theta \mathrm{XRD}, \alpha=1^{\circ}$ : 株リガク )およびフーリ 工変換赤外分光光度計 (FTIR: FT/IR-460Plus, 日本分光懒) に よる反射法により同定した. また, コーティング膜の断面観 察を透過型電子顕微鏡 (TEM: JEM-2100, 日本電子懒) により 行った.ブラスト処理基板上に作製されたHAp/OApコーティ ング膜の密着力測定を以下に示す方法で評価した ${ }^{22}$. エポキシ 系接着剤にてアルミニウム製スタッド (接着部直径: $2.7 \mathrm{~mm}$, P/N901106, Quad Group)をHAp/OApコーティング膜表面に接 着する. その後, 薄膜強度試験機 (Romulus IV, Quad Group) を用いたスタッドの引張試験において測定される最大荷重か らコーティング膜の密着強度を評価した．5つの試料で測定 を行ら, 密着強度の平均値および標準偏差を算出した. なお, 本研究で用いた接着剤の接着強度は $60 \sim 70 \mathrm{MPa}$ 程度である. 引張試験後の試料断面を走查型電子顕微鏡(SEM: XL30-FEG, PHILIPS (侏)によより観察した.

生体内評価として, スクリュー型ブラスト Ti-6Al-4Vイン プラントの埋入後の回転除去トルク測定を行った. HAp/OAp および ACP コーティングを施したスクリュー型ブラスト Ti6Al-4Vインプラントを日本白色家兔 (雄, 平均体重 $3 \mathrm{~kg}$ ) 大腿 骨に埋入した. なお，コントロール材としてコーティングを 施さなかったスクリュー型ブラストTi-6Al-4Vインプラント を用いた. 埋入数は片側 3 本とし， 2 または 4 週後全身麻醉下 において, インプラント体を骨組織から回転除去するのに要

Table 1 Deposition conditions of HAp/OAp and OAp/ACP coating films.

\begin{tabular}{ccccccc}
\hline & & $P / \mathrm{W}$ & $C_{\mathrm{O} 2}(\%)$ & $P_{\text {tot }} / \mathrm{Pa}$ & $t_{\text {depo }} / \mathrm{ks}$ & Heat treatment \\
\hline \hline \multirow{2}{*}{ HAp/OAp } & Inner & 150 & 50 & 0.5 & 9.6 & $873 \mathrm{~K}, 7.2$ ks in air \\
\cline { 2 - 7 } & Outer & 100 & 0 & 0.5 & 3.6 & - \\
\hline \multirow{2}{*}{ OAp/ACP } & Inner & 150 & 0 & 5 & 13.1 & - \\
\cline { 2 - 7 } & Outer & 100 & 0 & 0.5 & 3.6 & - \\
\hline
\end{tabular}


するトルク值をトルクゲージ(ATG24CH BTG150CN, 侏東日 製作所)により測定した. 各条件における埋入数は 5 とし, 平 均値および標準偏差を算出した。 また，コントロール材との 有意差を Studentのt検定により統計処理し，検定統計量から はずれる確率 $5 \%(\mathrm{p}<0.05)$ および $1 \%(\mathrm{p}<0.01)$ について評価 した. 回転除去トルク試験後の試料は樹脂埋め後, インプラ ント/骨界面をSEMにて観察した.

\section{3 結果と考察}

\section{1 二層リン酸カルシウムコーティング膜の構造}

Fig.1 およびFig.2に鏡面研磨基板上にOAp コーティング膜 を大気中熱処理して得られた第一層 $(\mathrm{HAp})$ と，その上に第二 層 (OAp)をコーティングした試料のXRDおよびFTIR スペク トルをそれぞれ示す.第一層のXRDパターンからは基板であ る $\alpha$-Ti以外に結晶性の高いHApのピークが確認された. また FTIR スペクトルからは $950 \sim 1100 \mathrm{~cm}^{-1}$ 付近に $\mathrm{PO}_{4}{ }^{3-}$ の振動に 由来するピークおよび $3572 \mathrm{~cm}^{-1} に \mathrm{OH}$ の伸縮に由来するピー クが確認された ${ }^{18)}$. OAp 相とHAp相は結晶構造が類似してい るが，XRDパターンにおけるOAp相とHAp相の $(00 l)$ ピーク 位置から判断できるとしている報告 ${ }^{1920)}$ がある. それらの報 告によれば, プラズマスプレー法により作製されたりン酸カ ルシウム膜は高温プロセスであるためにOAp相であるが, 熱 処理することで HAp 相に変態し，(002)のピークが高角側に シフトする. Fig.1の第二層コーティング後の XRD パターン において, HAp 構造の示す $25.9^{\circ}$ のピークの低角側に新たな ピークが観察されており,これはOAp相に起因するものと考 えられる. スパッタリング法によりチタン基板上に作製した

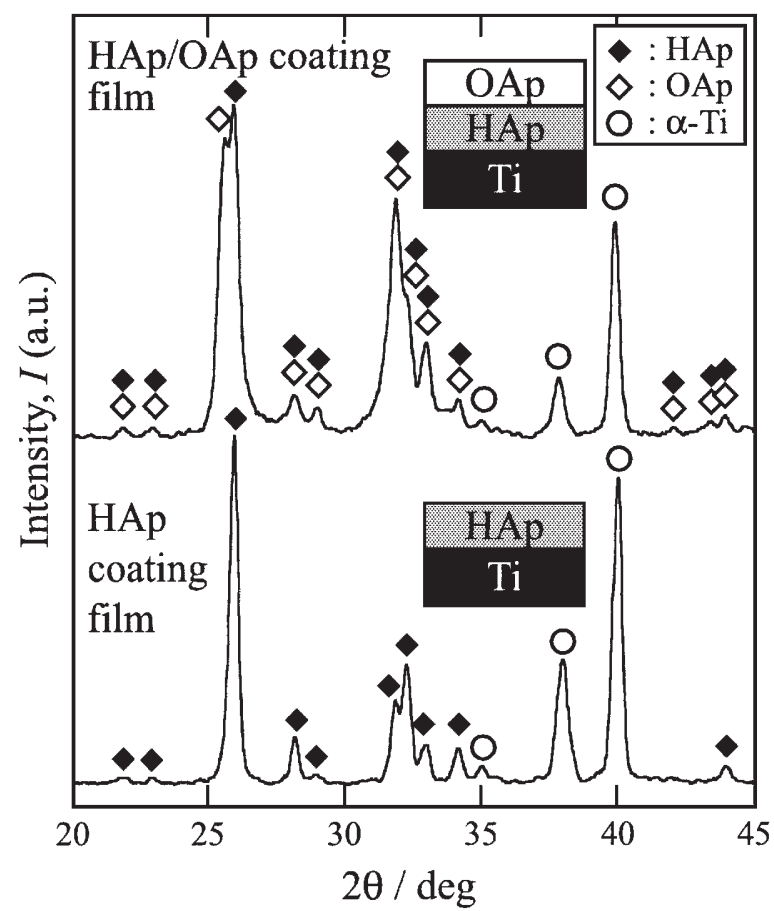

Fig.1 XRD patterns of HAp and HAp/OAp coating films fabricated on mirror-polished titanium substrates.
コーティング膜の熱処理に関して, Dijk ら ${ }^{21)}$ は大気中熱処理 によりコーティング膜の結晶度の向上と $\mathrm{OH}$ 基の導入が進行 することを示した. $\mathrm{OH}$ 基の導入は大気中の水蒸気が関連し た以下の式による.

$$
\mathrm{Ca}_{10}\left(\mathrm{PO}_{4}\right)_{6} \mathrm{O}(\mathrm{s})+\mathrm{H}_{2} \mathrm{O}(\mathrm{g}) \rightarrow \mathrm{Ca}_{10}\left(\mathrm{PO}_{4}\right)_{6}(\mathrm{OH})_{2}(\mathrm{~s})
$$

以上より作製された二層コーティング膜は基板側に $\mathrm{HAp}$ 相 を, 表面にはOAp相をそれぞれ有する構成であることが確認 できた．鏡面研磨基板上に作製された HAp/OAp コーティン グ膜の断面 TEM写真を Fig.3に示す. HAp コーティング膜上

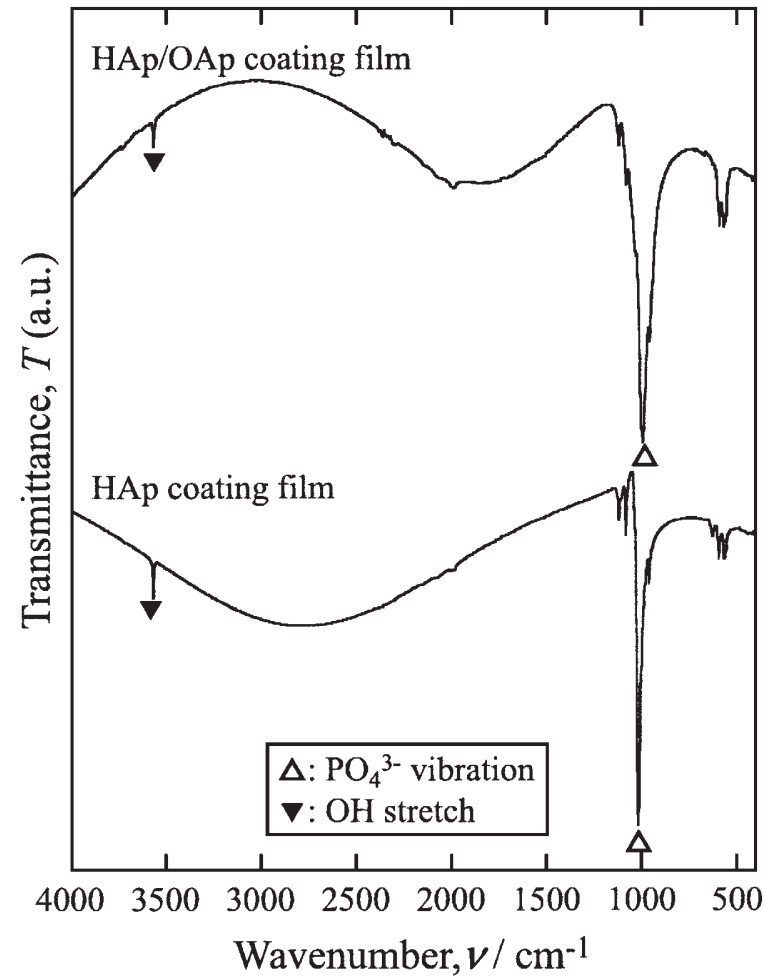

Fig.2 FTIR spectra of HAp and HAp/OAp coating films fabricated on mirror-polished titanium substrates.

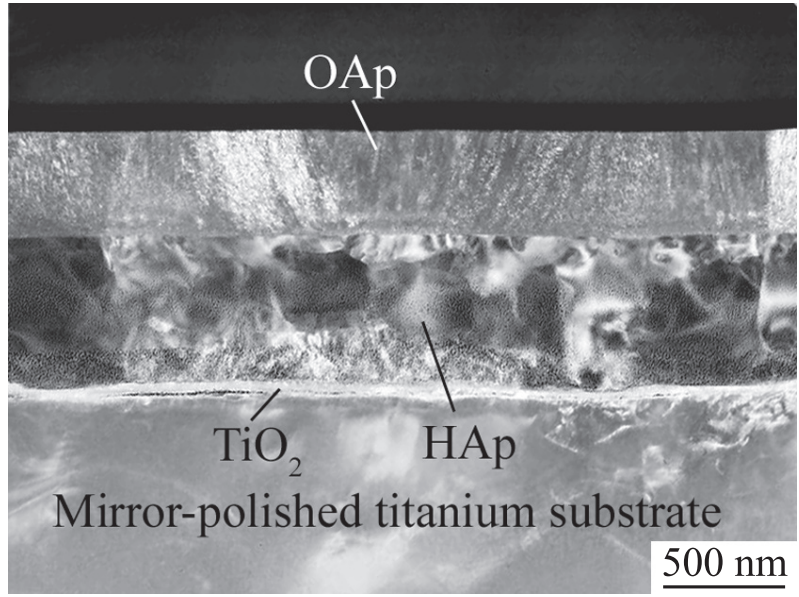

Fig.3 TEM image of the cross section of HAp/OAp coating film fabricated on mirror-polished titanium substrate. 
にOApコーティング膜がよく密着して均一かつ緻密に形成さ れていることが分かる. チタン基板とHApコーティング膜界 面に見られる層は熱処理により生成した $\mathrm{TiO}_{2}$ である. また， 熱処理によりHApコーティング膜の結晶粒径の増加が見て取 れる.

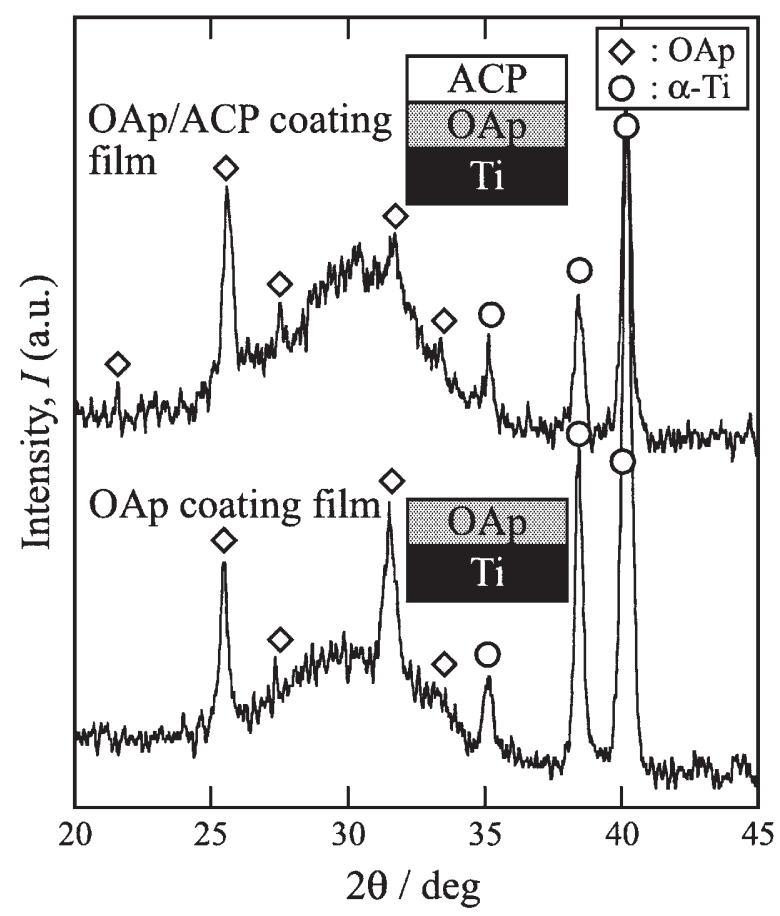

Fig.4 XRD patterns of OAp and OAp/ACP coating films fabricated on mirror-polished titanium substrates.

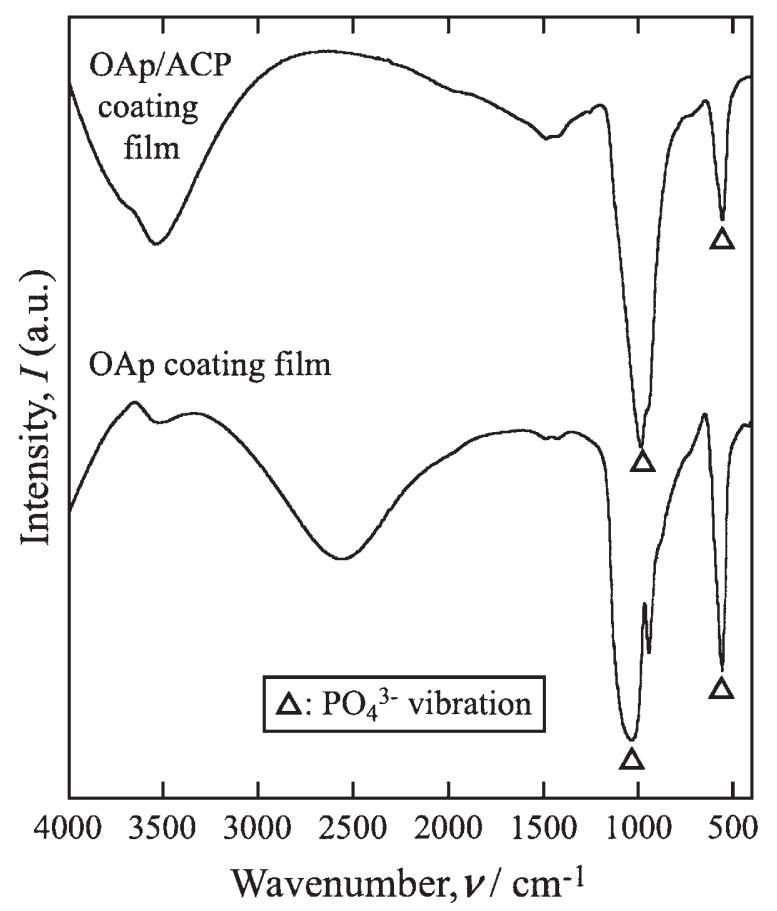

Fig.5 FTIR spectra of OAp and OAp/ACP coating films fabricated on mirror-polished titanium substrates.
Fig.4およびFig.5に鏡面研磨基板上に第一層であるOAp 相 を, その上に第二層として ACP相をコーティングした試料の XRD パターンおよびFTIR スペクトルをそれぞれ示す．第一 層の XRD パターンからは基板である $\alpha$-Ti のピーク以外に $2 \theta=30^{\circ}$ 付近のハローパターン, $2 \theta=25.4^{\circ}$ および $31.5^{\circ}$ に OAp 相のピークが確認された。第二層コーティング後の試料の XRD パターンからは OAp 相のピークは存在するものの, 八 ローパターンは第一層よりも顕著になり, OAp/ACPコーティ ング膜の形成が確認された. FTIRスペクトルからは, 第一層, 第二層コーティング後のいずれからも $\mathrm{OH}$ の伸縮に起因する ピークは確認されず, 前述の HAp/OAp コーティング膜のよ うな大気中での熱処理を伴わない場合には $\mathrm{OH}$ 基はコーティ ング膜中には存在しないことがわかる.

RFマグネトロンスパッタリング法により熱処理やスパッタ 条件を変化させることで, チタン基板上に結晶性や組成の異 なる二層コーティング膜を作製できた．前述の通り，これま でも RFマグネトロンスパッタリング法によるリン酸カルシ ウムコーティング膜作製においては, 多層化に関する研究が 行われてきたが ${ }^{14-17)}$, チタンとHApの多層化のみである. 本 研究においては熱処理やスパッタリング条件の制御により結 晶性や組成の異なったリン酸カルシウム膜の多層化を達成し ており, リン酸カルシウム相のみで基板/コーティング膜界 面およびコーティング膜/生体界面の制御が可能であること が示唆された。

\section{2 生体外評価}

現在実用化されている人工歯根はいずれもブラスト処理や 酸エッチングによる表面の粗造化が施されている. そこで本 研究においてもブラスト処理により粗造化させた基板とHAp/ OAp コーティング膜の密着力をピン引抜試験により評価し

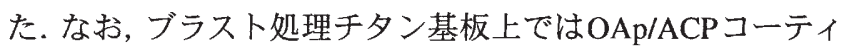
ング膜の相の確認が困難であり, OAp/ACPコーティング材の 生体外評価は行わなかった. Fig.6にブラスト処理基板上に作 製した HAp/OAp コーティング膜のピン引抜試験後の試料断 面 SEM 写真を示す. ピン引抜試験後においても HAp/OAp コーティング膜は剥離することなくブラスト処理基板上に 残っていた. また, ピン引抜試験時の最大加重より算出され

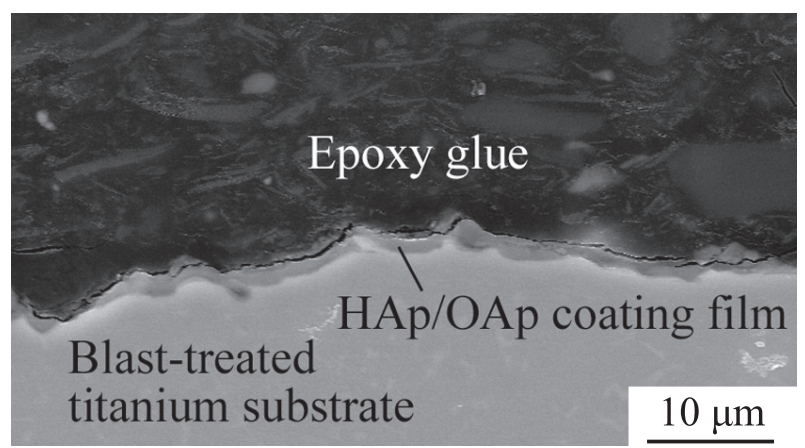

Fig.6 SEM image of the cross section of HAp/OAp coating film fabricated on blast-treated titanium substrate after pulling test. 
た密着力の平均値は $50 \mathrm{MPa}$ であったが，ピンの破断はコー ティング膜/接着剤界面もしくは接着剤内部にて生じたこと から,コーティング膜の密着力は本研究で用いた接着剤の接 着力 (60 70 MPa) 程度であると推察される. 生体材料として 用いられる場合のコーティング膜の密着強度はISOによると $50.8 \mathrm{MPa}$ 以上であるとされている ${ }^{7}$. 現在実用化されている プラズマスプレー法によるコーティング膜の密着力が20 30 $\mathrm{MPa}$ 程度であり ${ }^{22)}, \mathrm{HAp} / \mathrm{OAp} コ$ コイング膜は生体用として 十分な密着力を有していると評価できる.

\section{3 生体内評価}

HAp/OApをコーティングしたスクリュー型ブラストTi-6Al$4 \mathrm{~V}$ インプラントの家兔大腿骨からの回転除去トルク值を Fig.7に示す．なお，比較としてコーティング無し材 (コント ロール)およびACPコーティング材の結果も示した.いずれ の試料においても埋入期間の增加に伴い回転除去卜ルク值は 増加した. 2 週, 4週のいずれの週齢においてもコントロール

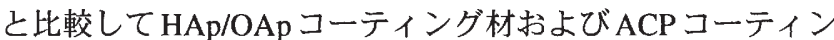
グ材の平均回転除去トルク值は高い值を示しておう, 特に埋 入 2 週後においては有意差も確認された. 4 週埋入後回転除 去トルク試験により引き抜いたスクリュー型ブラストTi-6Al4Vインプラントと骨の界面をSEM観察した結果をFig.8に示 す. 4 週埋入後においてはスクリュー型ブラスト Ti-6Al-4V インプラントと骨との接着が進行しており, 回転除去の際に 周囲骨も一緒に除去された. コントロールにおいてはインプ ラント/骨界面に一部隙間が存在していた。一方, HAp/OAp コーティング材は, コーティング膜がインプラント上に残っ

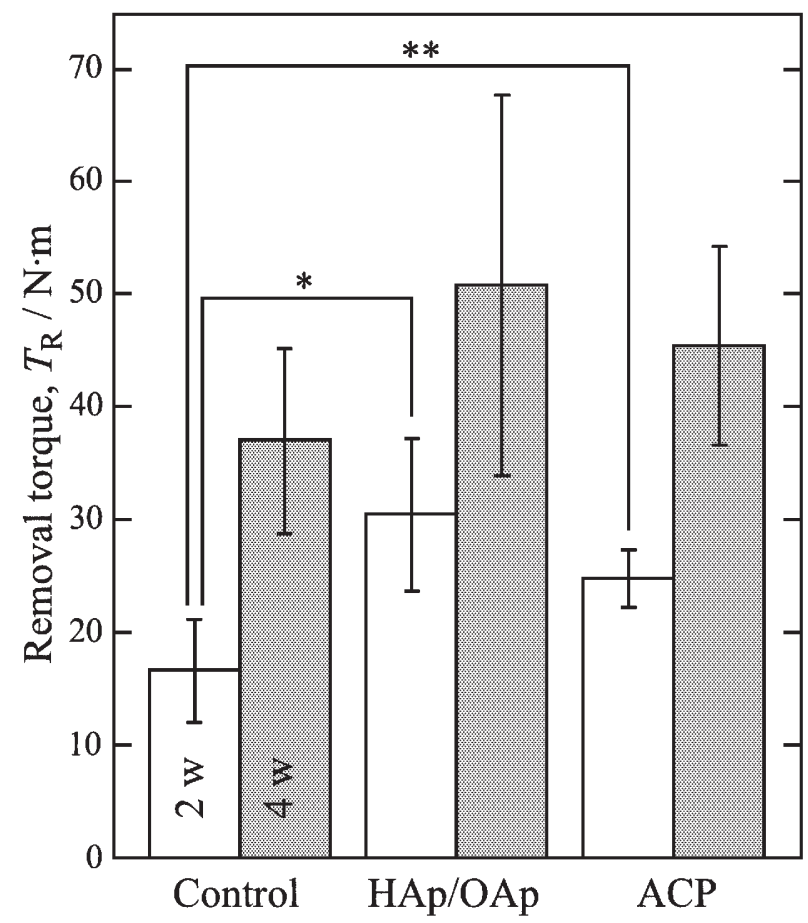

Fig.7 Removal torque values of non-, HAp/OAp- and ACP-coated blast-treated titanium implants 2 and 4 weeks after implantation $(* \mathrm{p}<0.05, * * \mathrm{p}<0.01)$.
ており，コーティング膜と骨とが直接接着していた．また， $\mathrm{ACP}$ コーティング材においては, コーティング膜は観察され ずインプラントと骨とが直接接触していた. これまでの当グ ループの研究から生体吸収性に関しては ACP > OAp > HAp (OApの大気中熱処理により作製)であることが示唆されてい る ${ }^{13)}$. 本研究の生体内評価においては，コーティング膜/骨

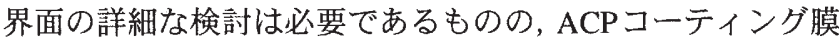
に関しては生体埋入後に溶解し, 新生骨形成を促進したと考 えられる.一方, HAp/OApコーティング膜においては, 表面 層である結晶性の低いOApコーティング膜が溶解することで 新生骨形成が促進され, HAp コーティング膜と新生骨とが直 接接着したものと考えられる.
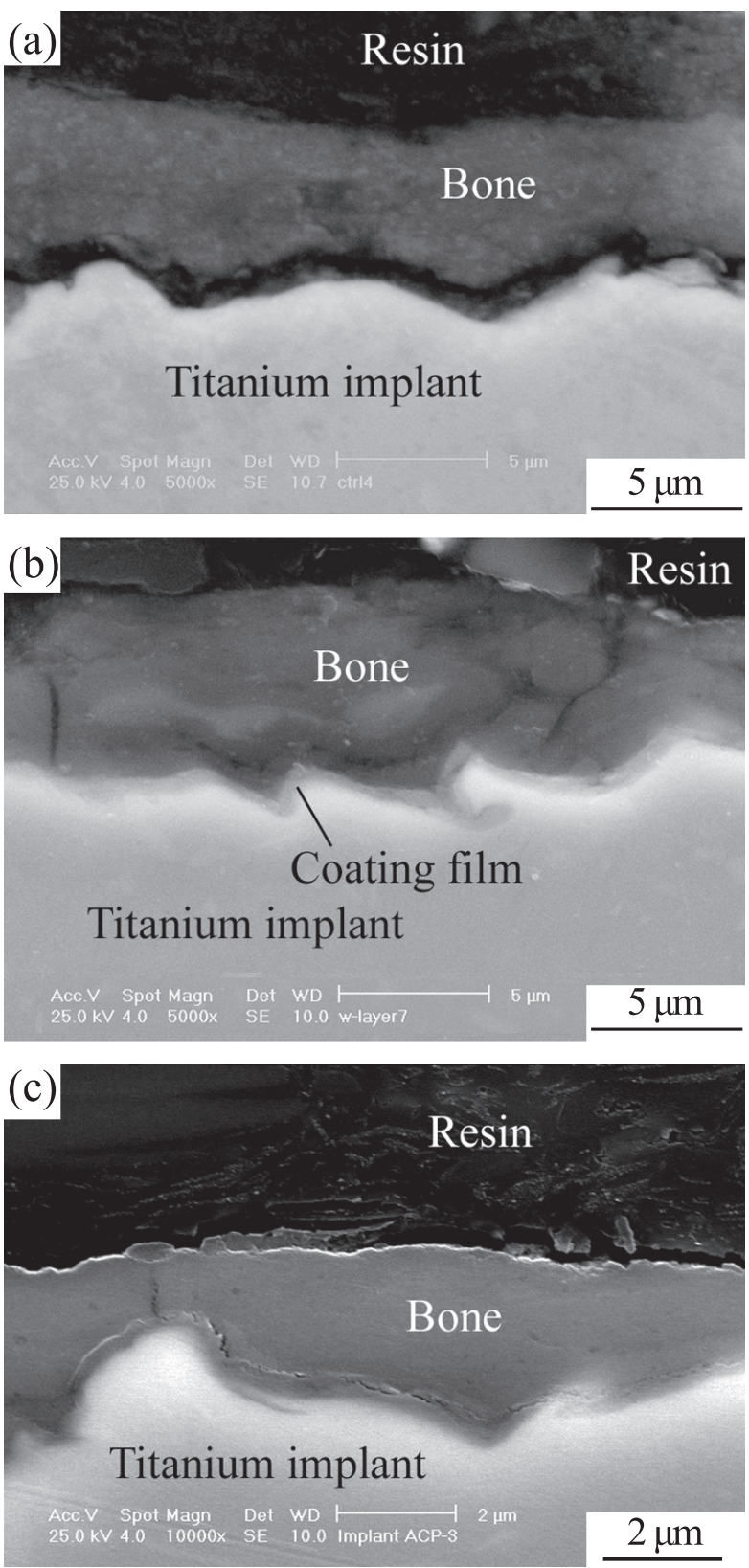

Fig.8 SEM images of the cross section of (a) non-, (b) HAp/OApand (c) ACP-coated blast-treated titanium implants after removal torque measurements (4-week implantation). 
これまで報告されている RFマグネトロンスパッタリング 法により作製された多層コーティング膜は, 基板との密着力 向上を目的としたTi/HAp多層コーティング膜の作製であり, その評価は密着力のみであった. 本報では, 基板との密着力 および骨形成能に着目し, リン酸カルシウムの結晶性や組成 を制御した二層コーティング膜が生体用として十分な特性を 有することを示すことができた. 生体内に埋入した際は, 基板/ コーティング膜界面およびコーティング膜/生体界面という $2 つ の$ 界面を考慮した材料設計が求められるが, 本研究で採 用した RF マグネトロンスパッタリングを利用した膜質制御 は生体応用のためのリン酸カルシウムコーティング高機能化 のための有力な方法であることがわかった.

\section{4 まと め}

チタン基板上へ RF マグネトロンスパッタリング法により 結晶性や組成の異なる二首構造を有するリン酸カルシウム コーティング膜を作製すると共に，その生体内外評価を行っ た. 得られた結果は以下の通りである.

(1) プロセス中に熱処理を加えることで, チタン基板側に結 晶性の高いHAp 層を, 生体側に結晶性の低いOAp 層を有 する二層コーティング膜を作製することができた.また， スパッ夕条件を変化させることで $\mathrm{OAp} / \mathrm{ACP}$ 二層コーティ ング膜を作製することができた．いずれも基板とよく密 着した均一かつ緻密なコーティング膜であった.

(2) HAp/OApコーティング膜とブラスト処理基板との密着力 は $50 \mathrm{MPa}$ 以上であり, 生体用コーティング膜としては十 分な值であった。

(3) スクリュー型ブラストTi-6Al-4Vインプラントの家兔大腿 骨からの回転除去トルク值は, HAp/OAp コーティングを 施したものはコーティングなしと比べ有意に高い値で あった．結晶化度の低い OAp コーティング膜が溶解し， HAp コーティング膜と骨とが直接密着していた.

\section{謝辞}

本研究の一部は日本学術振興会科学研究費補助金基盤研究 B (19360324), 文部科学省「生体ーバイオマテリアル高機能 インターフェース科学推進事業」およびJSTプラザ宮城「シーズ 発掘試験」の援助により行われたものであり，謝意を表する.

\section{文献}

1) H.E. Götz, M. Müller, A. Emmel, U. Holzwarth, R.G. Erben, and R. Stabgl: "Effect of Surface Finish on the Osseointegration of Laser-treated Titanium Alloy Implants", Biomaterials, 25 (2004) 4057-4064.

2) P-I. Brånemark: "Osseointegration and its experimental background", J. Prosthet. Dent., 50(1983)399-410.

3) M. Niinomi: "Recent Research and Development in Titanium Alloys for Biomedical Applications and Healthcare Goods", Science and Technology of Advanced Materials, 4(2003)
445-454.

4) T. Narushima: "Titanium and its Alloys as Biomaterials", J. Jpn. Light Metals, 55(2005)561-565.

5) L.L. Guéhennec, A. Soueidan, P. Layrolle, and Y. Amoriq: "Surface Treatment of Titanium Dental Implants for Rapid Osseointegration", Dent. Mater., 23(2007)844-854.

6) M. Wei, H.M. Kim, T. Kokubo, and J.H. Evans: "Optimising the Bioactivity of Alkaline-treated Titanium Alloy", Mater. Sci. Eng. C, 20(2002) 125-134.

7) Y. Yang, K.-H. Kim, and J.L. Ong: "A Review on Calcium Phosphate Coatings Produced Using a Sputtering Process-an Alternative to Plasma Spraying", Biomaterials, 26 (2005) 327-337.

8) T. Narushima, K. Ueda, T. Goto, H. Masumoto, T. Katsube, H. Kawamura, C. Ouchi, and Y. Iguchi: "Preparation of Calcium Phosphate Films by Radiofrequency Magnetron Sputtering", Mater. Trans., 4(2005)2246-2252.

9) K. Ueda, T. Narushima, T. Katsube, H. Kawamura, and T. Goto: "In Vitro Evaluations of RF Magnetron-sputtered Calcium Phosphate Films on Titanium", Key Eng. Mater., 352(2007) 305-309.

10) K. Ueda, T. Narushima, T. Goto, T. Katsube, H. Nakagawa, H. Kawamura, and M. Taira: "Evaluation of Calcium Phosphate Coating Films on Titanium Fabricated Using RF Magnetron Sputtering", Mater. Trans., 48(2007)307-312.

11) K. Ueda, T. Narushima, T. Goto, M. Taira, and T. Katsube: "Fabrication of Calcium Phosphate Films for Coating on Titanium Substrates up to $773 \mathrm{~K}$ by RF magnetron Sputtering and their Evaluations", Biomedical Materials, 2(2007) S160-S166.

12) T. Narushima, K. Ueda, T. Goto, T. Katsube, H. Kawamura, H. Nakagawa, and M. Taira: "Fabrication and Evaluation of Calcium Phosphate Coating Films on Blast-treated Ti-6Al4V Alloy Substrate", J. Jpn. Soc. Powder Powder Metallurgy, 55(2008)318-324.

13) K. Ueda, Y. Kawasaki, T. Narushima, T. Goto, J. Kurahara, H. Nakagawa, H. Kawamura, and M. Taira: "Calcium Phosphate Films with/without Heat Treatments Fabricated Using RF Magnetron Sputtering", J. Biomech. Sci. Eng., 3 (2009)392-403.

14) S.-J. Ding, C.-P. Ju, and J.-H.C. Lin: "Immersion Behavior of RF Magnetron-assisted Sputtered Hydroxyapatite/titanium Coatings in Simulated Body Fluid", J. Biomed. Mater. Res., 47(1999)551-563.

15) S.J. Ding: "Properties and Immersion Behavior of Magnetronsputtered Multi-layered Hydroxyapatite/titanium Composite Coatings", Biomaterials, 24(2003)4233-4238.

16) V. Nelea, C. Morosanu, M. Iliescu, and I.N. Mihailescu: "Microstructure and Mechanical Properties of Hydroxyapatite 
Thin Films Grown by RF Magnetron Sputtering", Surf. Coat. Technol., 173(2003)315-322.

17) M. Chen, D. Liu, C. You, X. Yang, and Z. Cui: "Interfacial Characteristic of Graded Hydroxyapatite and Titanium Thin Film by Magnetron Sputtering", Surf. Coat. Technol., 201 (2007) 5688-5691.

18) J.C. Elliott: Structure and Chemistry of the Apatites and other Calcium Orthophosphate, Elsevier, (2003) 171.

19) K.A. Gross, C.C. Berndt, P. Stephens, and R. Dinnebier: "Oxyapatite in Hydroxyapatite Coatings", J. Mater. Sci., 33 (1998)3985-3991.
20) K.A. Gross, V. Gross, and C.C. Berndt: "Thermal Analysis of Amorphous Phases in Hydroxyapatite Coatings", J. Am. Ceram. Soc., 81(1998) 106-112.

21) K. van Dijk, H.G. Schaeken, J.G.C. Wolke, and J.A. Jansen: "Influence of Annealing Temperature on RF Magnetron Sputtered Calcium Phosphate Coatings", Biomaterials, 17 (1996) 405-410.

22) S.W. K. Kweh, K.A. Khor, and P. Cheang: "An in vitro investigation of plasma sprayed hydroxyapatite (HA) coatings produced with flame-spheroidized feedstock", Biomaterials, 23 (2002)775-785. 